\title{
Impact of eLearning Perception and eLearning Advantages on eLearning for Stress Management (Mediating Role of eLearning for Corporate Training)
}

\author{
Aamir Sarwar \\ Institute of Business \& Information Technology \\ University of the Punjab, Lahore \\ asarwar@gmail.com \\ Chitapa Ketavan \\ Graduate School of eLearning \\ Assumption University of Bangkok, Thailand \\ chitapaktv@au.edu \\ Nadeem Shafique Butt \\ Department of Family and Community Medicine, Faculty of Medicine in Rabigh, King Abdul- \\ Aziz University, Jeddah, Kingdom of Saudi Arabia \\ nshafique@kau.edu.sa
}

\begin{abstract}
The objective of the study was to develop a model with and without the mediator comparing direct and indirect Impacts using Bootstrap (Two tailed significance results to be used), options for manufacturing, services sectors and overall and finding out the significance of the relationship. Study tried to find out the Impact of eLearning Perception and eLearning Advantages on eLearning for Stress Management with eLearning for Corporate Training as a mediator. This is a cross sectional study conducted in Pakistan. Detailed questionnaire was used to collect the data. Total sample size of 686 includes 331 from manufacturing sector and 355 from services sector. Study revealed that overall eLearning for corporate training partially mediates relationship between eLearning Perception and elearning for stress management. However, in subgroup of manufacturing sector full mediation is observed. eLearning for corporate training partially mediates relationship between eLearning Advantages and Stress management training. Similar partial mediation is observed for subgroups of manufacturing and services sector. However in subgroup of manufacturing sector no mediation was observed.
\end{abstract}

Key Terms: eLearning perception, eLearning Advantages, eLearning for Corporate Training, eLearning for Stress Management.

\section{Introduction}

Employees always desire to work in stress free environment in order to succeed in an organization. It is the responsibility of the management to ensure to provide enough support for the employees to overcome stress. Employers should identify the areas where the staff experiences stress and take action to reduce it. Hence, it is important to encourage employees to take stress management workshops if required. For that purpose organization take different steps to curb stress among employees or take necessary measures to manage stress among employees including:

1. Customized corporate seminars and workshops to help employees to understand the importance of stress free work environment. 
2. Individual review session with the employees to determine the different kind of problems they face.

3. Helping employees to improve their personality and on how to deal with difficult people and work situations.

4. Stress management solutions to maintain a perfect balance between personal and professional life. These solutions help the employees in recognizing and reducing stress symptoms before they become a real problem for themselves, their families and for the organization.

5. The stress management experts teach how to use different tools for staying calm and composed under different unusual situations.

6. The most important factor of the stress management program is to provide motivation to employees for a successful personal and professional life. So that can be more productive and contribute towards the success of their organization and can have satisfactory family life.

eLearning because of the different advantages it offer is also being used for different type of corporate trainings including stress management. This study focussed on corporate sector employees including manufacturing and services sector, their perception of eLearning and advantages of eLearning. How they perceive use of eLearning for corporate training and use of eLearning for stress management. Focus of the study is to find out and explore the mediating role of eLearning for corporate training between the impact of eLearning perception and eLearning advantages and eLearning for stress management.

\section{Stress and Work Stress}

Work Stress in corporate sector is not a recent phenomenon and it is also not linked to any specific type of industry or sector. Work Stress may differ from industry to industry or even from country to country. This trend-coupled with its rising cost to the individual, to industry and to society as a whole has greatly heightened awareness of the need for understanding stress and then effectively and innovatively finding the ways of tackling stress. There are many definitions of stress. Stress and work stress has been defined by different authors in different perspectives.

Stress is an element being experienced by employees around the globe. Stress is becoming a real problem for organization specially in developing nations where the employer does not realize the extent to which stress in having impact on the performance of employees that in the long run results in critical managerial difficulties (Subha \& Ahmad, 2009).

Baron (1983) defined stress as psychological and physiological anxiety that is experienced whenever work environment demands exceed a person's coping abilities.

As mentioned in Canadian Union of Public Employees (CUPE) (2003), European Commission's official definition of work-related stress is: "A pattern of emotional, cognitive, behavioral and physiological reactions to adverse and noxious aspects of work 
content, work organization Enough Workplace Stress: Organizing for Change and work environment."

According to Jamal and Baba (2000) "job stress indicates a poor fit between the individual abilities and the work environment in which either excessive demands are made on the individual or the individual is not fully equipped to handle a particular situation".

Job stress can be defined as the damaging and physical reactions that occur when job requirements do not match abilities, resources, or requirements of the worker. Job stress can lead to poor health and injury (NIOSH Working Group, 1999).

Various definitions have been proposed to explain job related stress. Factors usually associated with the work Stress include the following:

- Work Under load

- Work Overload

- Number of working hours

- Level of autonomy

- Role Conflict and Ambiguity

- Role of Supervision

- Changes in Family roles (Employees find it difficult to balance between the jobrelated responsibilities with the Family-related responsibilities)

- Effort reward imbalance

- Demanding Jobs (workload and autonomy of employees) may be the person who is doing a job may not be able to handle that job or he may not have the autonomy or powers to make decisions on his own and perform the task within the deadlines.

As described by Tennant (2001) the 1980s and 1990s has seen a significant change in the workforce structure in industrialized and developing economies. Employees are usually faced with greater demands and less job security, both results into stress, thus psychological disorders like depression may gradually be triggered by work-related stressors.

Stress as expressed by Stinchcomb (2004) is an occupational threat of modern living. In today's fast-paced, high-tech society, the debilitating effects of stress are not restricted to those engaged in police work. People from all fields of life and different professions and even the working mothers, stress have become as much a part of life in the 21 st century as computers and cell phones.

Robins (2001) defined stress as a vibrant condition in which the individual is challenged with an opportunity, constraint, or demand related to what he or she desires and for which the outcome is supposed to be both imprecise and important.

As mentioned by Cooper and Sutherland (2000) research evidence shown that a various reasons of work place conditions cause stress, strain or pressure that are associated with a wide range of physical and psychological health problems. (Smith, 2011) described that 
stress can be thought of as resulting from a disparity between demands placed on a person and the resources needed to deal with it. That is, pressure surpasses the assumed ability to cope.

Cooper and Williams (1998) described that stress is an vague and misrepresented term, and a system of measurement should provide a structure and a language that helps the understanding of the subject. One of the major factors hindering research into occupational stress is the inconsistency in the measurement methods.

Stress is a common experience in the life of employees at all levels of management. It is estimated that about 100 million workdays are being lost due to stress and nearly $50 \%$ to $75 \%$ disease are related to stress (Bashir, 2007).

A certain level of stress is positively related to job for an individual, any environment has a certain degree of stress, though of different nature. When stress is continued for a long period of time, the problem becomes substantial (Rajeshwari, 1992).

As discussed by Rahman and Zanzi (1995) studies in organizational behavior support the position that organizational structure have impact on the performance, employee satisfaction, and work related stress.

There are number of definitions of stress but Scott (2010) summarized the Stress as follows:

- Stress is the pressure that life applies on us and the way this pressure makes us feel.

- The reflex response to stress evolved from our need as humans to protect ourselves from real physical dangers - the "lions and tigers and bears" of early human history.

- In recent era, our stressors are mostly linked to different events in routine life, daily difficulties, technology, time limitations, targets, and personal communication.

- Stress contains cause and effect. Demands, challenges, or changes cause a series of actions that require modification. Our thoughts, actions, and behaviors can be considered the effects of these causes.

- These causes can be external or internal.

- These causes may produce different emotional, behavioral, and psychological reactions in each of us.

- Being exposed to causes is not the same as being susceptible to it.

- The stress development includes the mind and the body.

- Stress is in the eye of the beholder.

Stress in the workplace costs American businesses huge amounts of money. It is estimated that companies lose about $\$ 68$ billion every year from lost productivity and spend as much as $10 \%$ of their profits on stress-related debility claims (Gibson, 1993).

Stress affects the employees' performance that has impact on the organization existence because efficiency of employees is reduced and they cannot give their best to the 
organizations; this affects the performance of the organization in this competitive world and may endanger their existence. (Kazmi, Amjad, \& Khan, 2008).

Galinsky, Kim, and Bond (2001) mentioned that when people start feeling overworked, more chances of making mistakes; they are not happy with their employers; they have hard feelings about their coworkers who do not work hard like they do; that results into sleep disorders; and they also started feeling dissatisfied with their family and friends.

People who willingly decide to work more hours or days (Happy Workaholics) do not feel overworked have less chances to report these negative personal and organizational results. (Lobel, 2003)

Cooper and Sutherland (2000) mentioned that every era of this century has fetched its own exceptional changes to our working atmosphere. In the new millennium we must admit that (a) demographic changes and (b) Potential to improved communications that exist through different modes can be potential sources of stress.

Work stress has a significant importance for the organization and it has a direct impact on the employee's health and subsequently impacts work performance (Bytyqi, Reshani, \& Hasani, 2010).

DeFrank and Ivancevich (1998) described that many reasons of stress that exist these days are there for years, such as work overload; role conflict; ineffective, hostile and incompetent bosses; lack of personal fit with a job; lack of recognition; lack of a clear job description or chain of command; fear, uncertainty, and doubt about career progress; and prejudice based on age, gender, ethnicity or religion.

\section{eLearning}

eLearning can be defined as the delivery of learning through shared electronic technology which may include any or combination of the following:

1. Internet

2. Intranets

3. Extranets

4. Satellite broadcasts

5. Audio/video tapes

6. Interactive TV and

7. CD-ROM

Corporate sector world-wide keeps arranging trainings in-house and also keep sending its employees at different managerial levels for training locally and internationally but this involves a massive cost to them. This practice is very common in the big group of companies and multinational companies which arrange training as part of their policy to increase the working expertise of their employees. Globally, many consultants/consulting groups have the expertise to arrange different kind of trainings and they do customize the training modules according to the specific requirements of their corporate clients. One of 
the basic purposes of eLearning technology is that it is capable of reaching learners at distance, where conditions might prevent them from accessing full time education.

eLearning is not intended to substitute the old-style classroom setting, but to provide new opportunities for contact and communication between students and instructor or teacher (Masrom, 2007).

As explained by Garcia (2012) it was only a few seasons ago that considerations into the secluded frontiers of the eLearning field invited offering into blended learning, mobile learning, networked learning or maybe into complex adaptable eLearning systems, if we were really adventurous learning technologists.

As discussed by Zhang and Yuhao (2012) with the speedy development of information society and wide spread of life-long learning, the needs for knowledge are growing dramatically.

eLearning is nonlinear i.e. learners determine how, what and when they access information. It is a vibrant process - altered, custom-made and tailored on demand in response to learner and environmental variables. It is available on demand and just in time. The learner controls their own communication with the content and presentation (Chawla \& Jindia, 2011).

\section{Why does eLearning matter?}

In this new knowledge based economy, the gap between what we know and what we need to know to be competitive is growing day by day.

Learning that is enabled by electronic technologies, otherwise known as eLearning, can be either fully online, hybrid mode or web supported; however, regardless of the delivery method, there are number of tools and features available to instructors and students, and it is important for the eLearning community to study both inclinations and usage of these features (Buzzetto-More, 2008)

According to Nycz and Cohen (2007) eLearning is important for having a technology oriented workforce as well as for meeting society's ever changing need for fast and lifelong learning delivered in the most convenient method.

The convenience of eLearning training with on-demand availability, user controlled training speed and chunked segments were identified as elements that enhanced the eLearning training method (Ibrahim, Mohd Rozar, Razik, \& Kormin, 2011).

\section{Purpose of eLearning at Corporate Level}

As business world has also started using the eLearning considering its advantages and benefits to corporations, eLearning is here to stay and one can always expect to have more advanced techniques and more widely use of eLearning. eLearning will offer neverending benefits and opportunities to corporations using it wisely and will help reducing cost and increasing the benefits to the employees and corporations in general. Every business is striving for its existence in this competitive world by maximizing their profits, 
therefore, employing a successful eLearning strategy will help a corporation to reduce costs to a large extent, while increasing workplace satisfaction and rising employee motivation. It may be beyond our imagination that what a brilliant future of eLearning is going to be and the benefits its users will be having in future.

\section{eLearning Advantages}

Like conventional system of learning, eLearning have its advantages and disadvantages. Learners have the advantage of flexibility, convenience, reduced time and cost. Learners can learn at any time, at any place, and any pace according to his work and family requirements. Learners have the flexibility to select the course content according to their precise requirements.

As described by the Curran (2001) the new technologies have the capacity to stretch out to the economically and academically disadvantaged with a richer pedagogy than was previously possible, not least in the developing world.

eLearning is simply a method for delivering learning and it has its advantages and disadvantages like any other medium $(\mathrm{P}, 2007)$.

According to Edlington (2007) use of and dependence upon eLearning systems and methods in universities is often structured to achieve a range of proficiencies s, usually desired by senior management to achieve more within limited budgets.

\section{eLearning for Corporate Training}

eLearning is considered to be cost effective than conventional classroom instruction. In addition, many expenses - booking training facilities, travel costs for employees or trainers, plus employee time away from the job - are greatly reduced (Strother, 2002).

As mentioned by Capper (2001) corporate eLearning is one of the fastest growing and most promising markets in the academic industry.

As discussed by Tai (2008) corporations using eLearning do so for a many reasons. They do it for strategic reasons, accessibility, paced, geography, motivation and retention, productivity and investment purposes.

Strother (2002) mentioned that reduced cost, accessibility, standardized delivery, selfpaced learning, and wide variety of the available content, have made eLearning a high priority for many corporations. These days corporations are looking at such opportunities as blended learning, using more than one method of delivery.

According to Zornada (2005) internet technologies and the introduction of eLearning applications in many organizations have made a vital difference to the techniques used by the organizations to deliver training and development content, activities and experiences to their employees.

eLearning is a tool which is being used not only by the educational institutions but also by the corporate sector. 
Zornada (2005) concluded his study as follows:

1. Organisations are using eLearning as an increasing part of training strategy;

2. Organisations using eLearning are substituting eLearning based delivery of training and content for what was previously classroom based training;

3. eLearning is seen by many oganisations as a low risk e-business initiative and can be used as a model to the deployment of more comprehensive business critical intranet of extranet portals;

4. Many of the multinational companies have been at the forefront of following eLearning and set hostile targets for the amount of overall training to be transferred to eLearning;

5. There are real benefits to eLearning which suggest that in many training areas, it produces greater outcomes to classroom-based learning for the learner;

6. eLearning offers real cost and efficiency benefits for organisations;

7. eLearning is not universally applicable to all learning areas or interest to corporates;

8. The cost of developing and implementing an eLearning platform is huge and offers opportunities for independent organisations/consultants to develop and deliver this functionality to corporate clients.

9. Due to the huge mamlount of effort required to develop, update, convert and maintain content suggests that externally sourced content and out-sourced content management services will develop as a key feature of effective corporate eLearning implementations.

To respond to an ever changing and demanding work environment "just-in-time training" for employees, most of the organizations not only depend on conventional training, they have already moved to eLearning and stressing it in safety and health since they were trust of the benefits of eLearning training to the company cost effective (Ibrahim et al., 2011).

Corporate eLearning programs are planned to incite a change in people's capability to perform a professional function. Because of this reasons organizations are developing new organizational systems and procedures, new software's, services or products, new ethical and regulatory requirements, new marketing, sales or manufacturing initiatives, orientation of new staff or to improve customer service performance.

According to Sharma (2012) eLearning services have extended traction in the corporate sector because they play an pivotal role in educating corporate professionals and keeping their skills up to date. eLearning training techniques are being given preference by many organizations globally over the traditional classroom training sessions, since they easier to manage and customized for each group of learners. The companies they can opt for customized eLearning solutions for different departments and different level of managers.

\section{eLearning and Stress Management}

Recently, eLearning is becoming popular due to the advantages it offers to the corporate sector and also facilitates to the employees/learners. Besides, in order to remain competitive in the global market, the consultants and trainers need to develop efficient and effective learning systems to cater the requirements of the ever-changing and 
developing corporate sector. Advances in the technology and technology-led changes in the society are creating new paradigms in the area of training.

The prevention of stress demands that the reasons of stress be precisely identified. (Sutherland \& Cooper, 1996)

Stress management is very important in corporations as it have severe impacts not only on the individual who is facing it but it also have serious impact on productivity, quality and profitability of the organization.

Stress is not a medical condition but is based on the insight of an individual, thus what may appear stressful for one person may be seen as a challenge by another (Lawless \& Allan, 2004).

There is a possibility that online training courses will be available from anywhere employees may have internet access. eLearning series may include all of the online training tutorials listed and is provided in an interactive, self-paced format. Employee can repeat any or all of the training material for his training as many times as he wishes to do so.

Generally stress was seen as a public health issue, is gradually recognized as a workforce management issue. The good news is that stress management can be learned and leadership and coaching skills can be developed.

eLearning courses help managers, human resource professionals, supervisors, workers and individuals with an interest in

- $\quad$ Managing job stress

- Enhancing productivity

- Improving work life balance

Last but the least, one of the key benefits provided by eLearning is that despite of real geographical boundaries there are no real boundaries in learning environments.

Though there are many advantages of courses through eLearning, but still participants can have different thoughts and attitudes towards this recent process of learning. It may depend on different factors including the following:

1. Attitude of the participants

2. Participants perception of the advantage of such courses

3. Technology available at work place to deliver the content

4. Technological background, knowledge and orientation of the participants

5. Acceptability of IT by participants

6. Course content and how these course will be delivered

7. Relevancy of the eLearning course content with the participants and the organization they are working with.

8. Customization of the course content with the cultural background, knowledge and the level of the management of the participants. 
Our study tried to find out the attitude and perception of the employees working in the corporate sector of Pakistan, towards the usage of eLearning tools for training and specifically training related to management of work stress.

\section{Objective of the Study}

The objective of the study was to develop a model with and without the mediator comparing direct and indirect impacts using Bootstrap (Two tailed significance results to be used), options for manufacturing, services sectors and overall and finding out the significance of the relationship.

\section{Research Methodology}

Detailed Questionnaire was designed for the purpose of data collection. Response was measured on the likert scale (1 for strongly disagree and 5 for strongly agree). Areas covered in the questionnaire included the following:

1. Perception about eLearning and Advantages of eLearning (11)

2. eLearning Advantages (12)

3. Use of eLearning for corporate training and (16)

4. Use of eLearning for Work Stress Management (12)

\section{Target Population}

Target population for collecting the data was the different level of managers working in the manufacturing and services sector public limited and private limited organizations having their offices in Lahore, Pakistan.

\section{Location of Study}

The data was collected from city of Lahore which is one of the main cities of Pakistan. Lahore is having Industrial estates and number of large industries established in and around Lahore. Large number of companies offering services also has their regional and head offices in Lahore, Pakistan.

\section{Pakistan - Manufacturing and Services Sector}

In Pakistan, growth in manufacturing sector is not as high as compared to the services sector during the last decade. Pakistan is having a well-established agro-base industry like textile, Sugar. Besides, Dairy, Printing and Packaging, Leather, Automobile, Chemical \& Fertilizers industry are also contributing a great deal in the national exchequer. Textile sector itself has diversity including spinning, weaving, dyeing, stitching, Knitwear, and composite units.

During the recent past, services industry has grown tremendously not only in Pakistan but also worldwide. Due to the increase in usage of Internet and mobile phones, telecommunication and financial sector has shown unprecedented growth in Pakistan. Technology is now being used in almost every sector and financial sector is no exception. 
The Services sector contributes 53.8\% to Pakistan's GDP. Services contribution to the GDP of Pakistan is gradually increasing. Services sector accounts for 54 percent of GDP and little over one-third of total employment. Services sector has strong linkages with other sectors of economy; it provides essential inputs to agriculture sector and manufacturing sector.

\section{Data Collection}

Around 1,100 questionnaires were distributed, whereas, total duly filled questionnaires received back were 686 . So the response rate was almost $62.36 \%$.

\section{Sampling Technique}

Multi-stage sampling was used to collect the data as follows:

1. Selection of Public and Private Companies in each sector having offices in and around Lahore.

2. Finding details of employees (male as well as females) working at different levels of

3. Finding a contact person/HR manager to help to fill the questionnaires.

4. Data collected from employees (depending upon their availability and willingness to participate in research study) working at different levels of management; married and having kid(s)

Results: Three hundred plus samples were collected from manufacturing and services sectors

\section{Statistical Analysis}

IBM SPSS Statistics 21, Microsoft Excel and AMOS were used to find out the Impact of eLearning Perception and eLearning Advantages on eLearning for Stress Management with eLearning for Corporate Training as a mediator. Bootstrap two-sided p-value and Baron and Kenny (1986) approaches were used to see mediation effects.

MacKinnon, Lockwood, Hoffman, West, and Sheets (2002) placed the different regression tests of mediation into three categories: tests of causal steps, tests of the difference in coefficients, and tests of the product of coefficients. In the causal-steps approach, each of the four steps in the causal process must be true for mediation to be present (Judd \& Kenny, 1981). The four steps are as follows:

1. The total effect of $X$ (IV) on $Y$ (DV) must be significant.

2. The effect of $X$ (IV) on $M$ (Mediator) must be significant.

3. The effect of $M$ (Mediator) on $Y$ (DV) controlled for $X$ (IV) must be significant.

4. The direct effect of $X$ (IV) on $Y$ (DV) controlled for $M$ (Mediator) must be must be smaller than the total effect of $X(I V)$ on $Y(D V)$.

Models in which all four steps are satisfied are called fully mediated models. For one to conclude that mediation is present, each of the four steps must be satisfied. (Baron \& Kenny, 1986). 


\section{Reliability Test of Questionnaire}

To check the reliability of the data Cronbach's alpha was calculated. "Cronbach's alpha is a test for a model or survey's internal consistency, called a 'scale reliability coefficient sometimes.

\section{Table 1: Cronbach's Alpha Results}

\begin{tabular}{|l|l|l|}
\hline Perception of eLearning & 0.879 & 11 \\
\hline eLearning Advantages & 0.864 & 12 \\
\hline Perception of eLearning for Corporate Training & 0.905 & 16 \\
\hline Perception of eLearning for Stress Management & 0.941 & 12 \\
\hline
\end{tabular}

\section{Demographic Profile of Respondents}

Following table contains the profile of the 686 respondents.

\section{Table 2: Demographic Profile}

\begin{tabular}{|c|c|c|}
\hline Category & & Frequency $(\%)$ \\
\hline \multirow[t]{2}{*}{ Gender } & Male & $621(90.5)$ \\
\hline & Female & $65(9.4)$ \\
\hline \multirow[t]{5}{*}{ Age } & Under 26 & $69(10)$ \\
\hline & $26-35$ & $313(45.6)$ \\
\hline & $36-45$ & $176(25.6)$ \\
\hline & $46-45$ & $97(14.1)$ \\
\hline & $56+$ & $31(4.5)$ \\
\hline \multirow[t]{3}{*}{ Qualification } & Less than Bachelor & $36(5.2)$ \\
\hline & Bachelor & $218(31.7)$ \\
\hline & Higher than Bachelor & $432(62.9)$ \\
\hline \multirow[t]{5}{*}{ Experience } & $=<1$ year & $37(5.3)$ \\
\hline & $>1$ years and $=<3$ years & $86(12.5)$ \\
\hline & $>3$ years and $=<6$ years & $122(17.7)$ \\
\hline & $>6$ Years and $=<9$ Years & $131(19)$ \\
\hline & $>9$ years & $310(45.1)$ \\
\hline \multirow[t]{2}{*}{ Co Functions } & Manufacturing & $331(48.2)$ \\
\hline & Services & $355(51.7)$ \\
\hline \multirow[t]{3}{*}{ Mgmt. Level } & Senior Management & $124(18)$ \\
\hline & Middle Management & $384(55.9)$ \\
\hline & Lower Management & $178(25.9)$ \\
\hline
\end{tabular}

Both the sectors, manufacturing as well as services, had almost equal representation as we had $52 \%$ respondents from services sector and $48 \%$ from manufacturing sector. More than $80 \%$ respondents fall between the age of 26 and 45 years. Overall we had a good mix of respondents from both the sectors. 


\section{Data Analysis and Results}

Data Analysis was used to validate the following hypotheses:

Table 3: Hypotheses

\begin{tabular}{|c|l|}
\hline Hypotheses & Hypotheses Description \\
\hline $\mathrm{H}_{\mathrm{o}} 1:$ & $\begin{array}{l}\text { eLearning for Corporate Training mediates the relationship between } \\
\text { eLearning Perception and eLearning for Stress Management }\end{array}$ \\
\hline $\mathrm{H}_{\mathrm{o}} 2:$ & $\begin{array}{l}\text { eLearning for Corporate Training mediates the relationship between } \\
\text { eLearning Advantages and eLearning for Stress Management }\end{array}$ \\
\hline
\end{tabular}

The following model was developed using AMOS:

\section{Model Showing Mediation Impact}

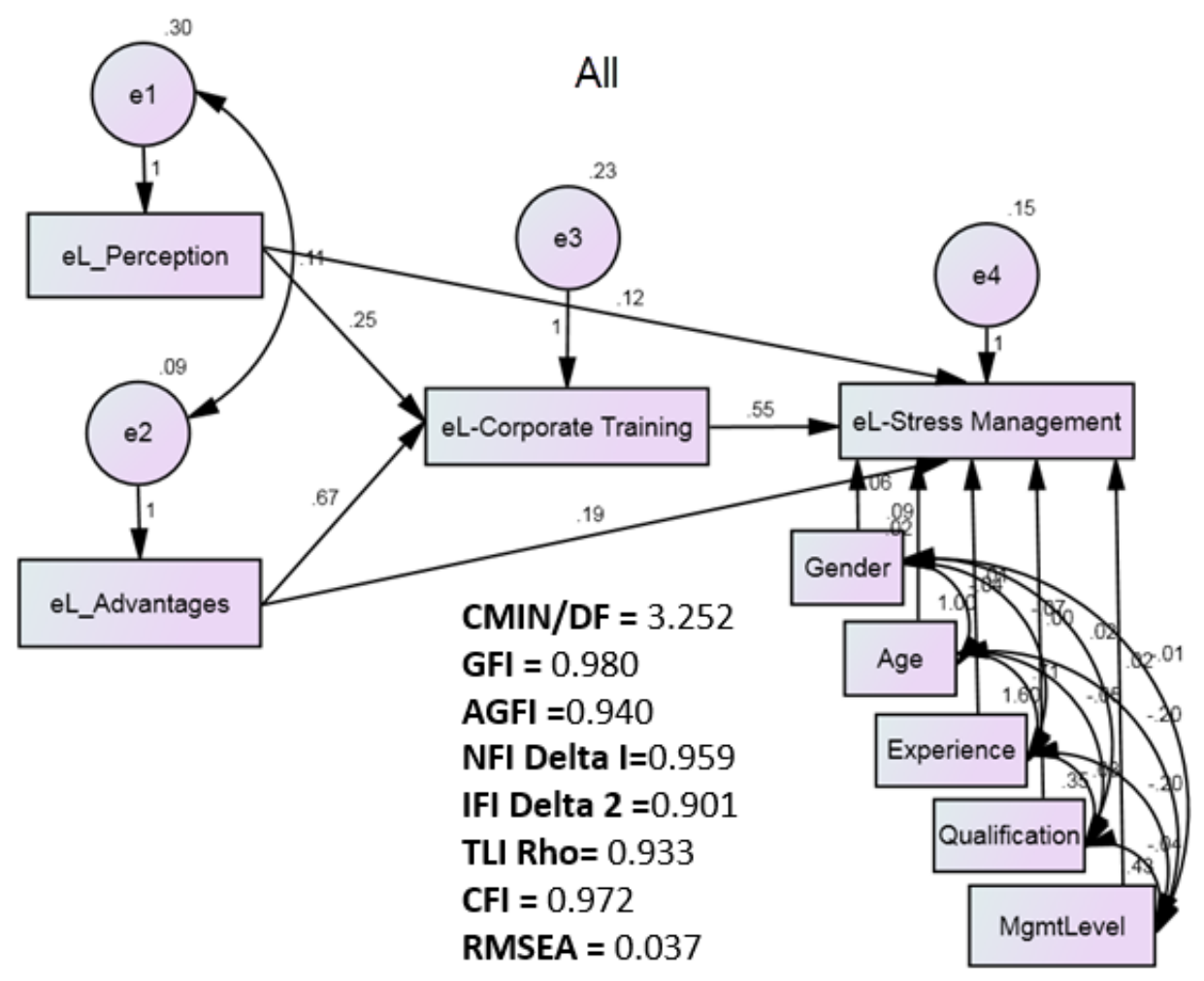

Figure 1: $\quad$ Model Developed Using AMOS showing the Mediation Impact 


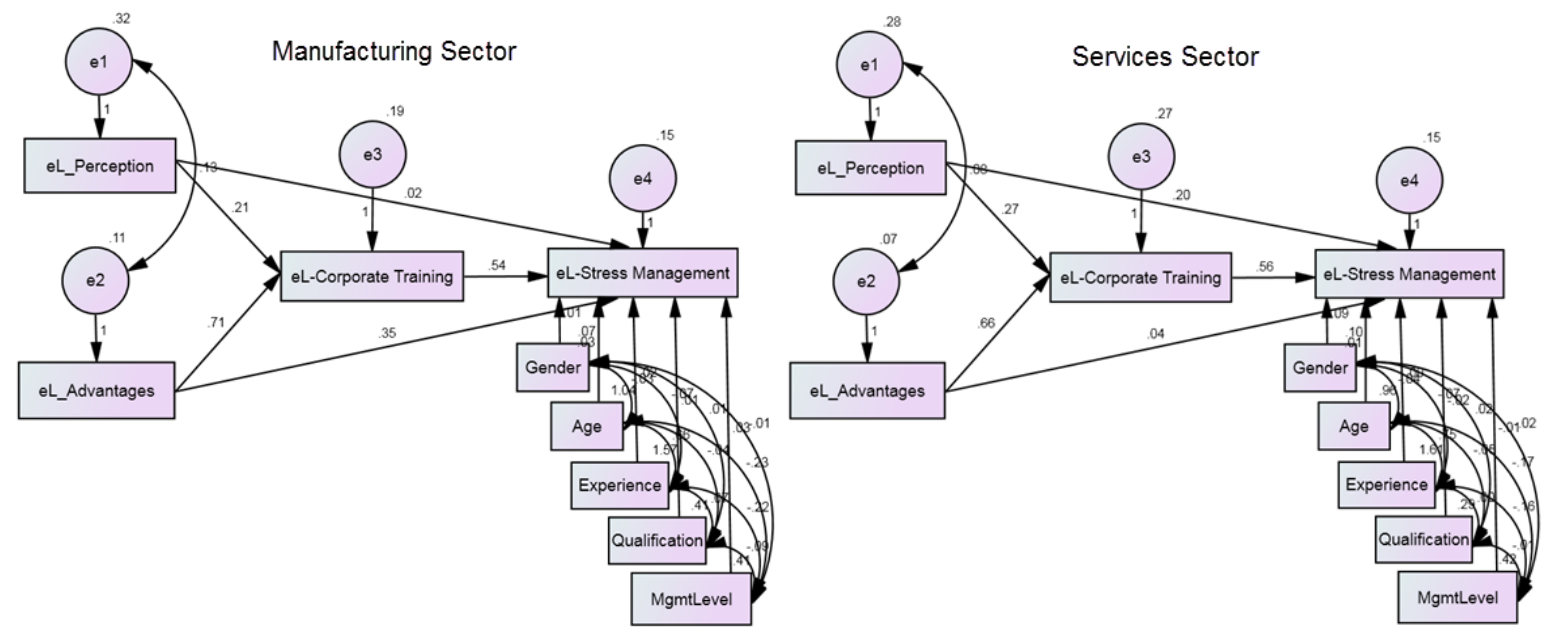

Figure 2: Model Developed Using AMOS showing the Mediation Impact Separate for Manufacturing and Services Sector

Results of the model are also reported in Figure 1. All the values meet the standards for the goodness of fit.

Table 4 is showing the results of the mediation model:

Table 4: Results of Mediation Model

\begin{tabular}{|c|c|c|c|c|c|c|c|}
\hline & $\begin{array}{c}\text { Independent } \\
\text { Variable (I V) }\end{array}$ & Mediator & $\begin{array}{c}\text { Dependent } \\
\text { Variable (D V) }\end{array}$ & $\begin{array}{c}\text { Without } \\
\text { Mediation }\end{array}$ & $\begin{array}{c}\text { With } \\
\text { Mediation }\end{array}$ & $\begin{array}{c}\text { Indirect } \\
\text { Bootstrap }\end{array}$ & Remarks \\
\hline \multirow{2}{*}{$\equiv$} & $\begin{array}{l}\text { eLearning } \\
\text { Perception }\end{array}$ & $\begin{array}{c}\text { eLearning } \\
\text { Corporate } \\
\text { Training }\end{array}$ & $\begin{array}{l}\text { Stress Mgmt } \\
\text { Training }\end{array}$ & $\begin{array}{c}0.2525 \\
(0.0000)\end{array}$ & $\begin{array}{c}0.1203 \\
(0.0011)\end{array}$ & 0.010 & $\begin{array}{c}\text { Partial } \\
\text { Mediation }\end{array}$ \\
\hline & $\begin{array}{c}\text { eLearning } \\
\text { Advantages }\end{array}$ & $\begin{array}{c}\text { eLearning } \\
\text { Corporate } \\
\text { Training }\end{array}$ & $\begin{array}{l}\text { Stress Mgmt } \\
\text { Training }\end{array}$ & $\begin{array}{c}0.5477 \\
(0.0000)\end{array}$ & $\begin{array}{c}0.6700 \\
(0.0000)\end{array}$ & 0.010 & $\begin{array}{c}\text { Partial } \\
\text { Mediation }\end{array}$ \\
\hline \multirow{2}{*}{ 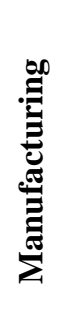 } & $\begin{array}{l}\text { eLearning } \\
\text { Perception }\end{array}$ & $\begin{array}{c}\text { eLearning } \\
\text { Corporate } \\
\text { Training }\end{array}$ & $\begin{array}{l}\text { Stress Mgmt } \\
\text { Training }\end{array}$ & $\begin{array}{c}0.1355 \\
(0.0280)\end{array}$ & $\begin{array}{c}0.0237 \\
(0.6632)\end{array}$ & 0.012 & Mediation \\
\hline & $\begin{array}{l}\text { eLearning } \\
\text { Advantages }\end{array}$ & $\begin{array}{c}\text { eLearning } \\
\text { Corporate } \\
\text { Training }\end{array}$ & $\begin{array}{l}\text { Stress Mgmt } \\
\text { Training }\end{array}$ & $\begin{array}{c}0.7254 \\
(0.0000)\end{array}$ & $\begin{array}{c}0.7068 \\
(0.0000)\end{array}$ & 0.064 & $\begin{array}{c}\text { No } \\
\text { Mediation }\end{array}$ \\
\hline \multirow{2}{*}{$\frac{⿱ 乛 龰}{2}$} & $\begin{array}{l}\text { eLearning } \\
\text { Perception }\end{array}$ & $\begin{array}{c}\text { eLearning } \\
\text { Corporate } \\
\text { Training }\end{array}$ & $\begin{array}{l}\text { Stress Mgmt } \\
\text { Training }\end{array}$ & $\begin{array}{c}0.3537 \\
(0.0000)\end{array}$ & $\begin{array}{c}0.2044 \\
(0.0000)\end{array}$ & 0.011 & $\begin{array}{c}\text { Partial } \\
\text { Mediation }\end{array}$ \\
\hline & $\begin{array}{l}\text { eLearning } \\
\text { Advantages }\end{array}$ & $\begin{array}{c}\text { eLearning } \\
\text { Corporate } \\
\text { Training }\end{array}$ & $\begin{array}{l}\text { Stress Mgmt } \\
\text { Training }\end{array}$ & $\begin{array}{c}0.3931 \\
(0.0000)\end{array}$ & $\begin{array}{c}0.6575 \\
(0.0000)\end{array}$ & 0.027 & $\begin{array}{c}\text { Partial } \\
\text { Mediation }\end{array}$ \\
\hline
\end{tabular}




\section{Results and Discussion}

In Step-1 of the mediation model, the regression of eLearning Perception on elearning for Stress management, ignoring the mediator eLearning for Corporate training, was significant, $\mathrm{b}=0.2525$ with $\mathrm{p}=.0000$. Step- 2 showed that the regression of eLearning Perception on eLearning for Stress Management training with mediator eLearning for corporate training is also significant, $\mathrm{b}=0.1203$ with $\mathrm{p}=.0000$. Step- 3 , the indirect (mediated) effect of eLearning Perception on eLearning for Stress Management training is significantly different from zero at the 0.01 level ( $\mathrm{p}=.010$ two-tailed, this is bootstrap approximation obtained by constructing two-sided percentile-based confidence intervals). Since direct affects both with and without mediator found to be significant and also indirect direct effect is significant so we can say that eLearning for Corporate training partially mediates relationship between eLearning Perception and eLearning for Stress Management training. However, in subgroup of manufacturing sector full mediation is observed as direct relationship without mediator is significant $(b=0.1355$ with $\mathrm{p}=0.0280)$ and this became insignificant $(\mathrm{b}=0.0237$ with $\mathrm{p}=0.6632)$ in presence of mediator and indirect effect is significant (0.012).

The mediation model, Step-1, the regression of eLearning Advantages on eLearning for Stress Management training, ignoring the mediator eLearning for Corporate training, was significant, $\mathrm{b}=0.5477$ with $\mathrm{p}=.0000$. Step- 2 showed that the regression of eLearning Advantages on eLearning for Stress Management training with mediator eLearning for Corporate training is also significant, $b=0.6700$ with $p=.0000$. Step-3, the indirect (mediated) effect of eLearning Advantages on eLearning for Stress Management training is significantly different from zero at the 0.01 level $(\mathrm{p}=.010$ two-tailed, this is bootstrap approximation obtained by constructing two-sided percentile-based confidence intervals). Since direct effects both with and without mediator found to be significant and also indirect effect is significant so we can say that eLearning for Corporate training partially mediates the relationship between eLearning Advantages and Stress management training. Similar partial mediation is observed for subgroups of services sector.

Since direct affects both with $(b=0.7254$ and $p=0.0000)$ and without mediator $(b=0.7068$ and $\mathrm{p}=0.000$ ) found to be significant and indirect effect at 0.01 and even at 0.05 level $(\mathrm{p}=0.064$, two-tailed, this is bootstrap approximation obtained by constructing two-sided percentile-based confidence intervals) is insignificant so we can say that no evidence of mediation.

\section{References}

1. Baron, R. M., \& Kenny, D. A. (1986). The moderator-mediator variable distinction in social psychological research: Conceptual, strategic, and statistical considerations. Journal of personality and social psychology, 51(6), 1173.

2. Bashir, A. (2007). Employees' Stress and Its Impact on Their performance. Paper presented at the First proceedings of International Conference on Business and Technology, Islamabad.

3. Buzzetto-More, N. A. (2008). Student Perceptions of Various E-Learning Components. Interdisciplinary Journal of E-Learning and Learning Objects, Volume 4, 113-135. 
4. Bytyqi, F., Reshani, V., \& Hasani, V. (2010). Work Stress, Job Satisfaction and Organizational Commitment among Public Employees before Privatization. European Journal of Social Sciences - Volume 18, Number 1, pp. 156-162.

5. Capper, J. (2001). The Emerging Market for On-Line Learning: Insights from the Corporate Sector. European Journal of Education, Vol. 36, No. 2, On-Line Learning, retieved from http://www.jstor.org/stable/1503654 · pp. 237-245.

6. Chawla, S., \& Jindia, A. (2011). Students' Inclination Towards E-Learning: A Study. International Journal of Emerging Technology and Advanced Engineering, Vol. 1, Issue 2, pp:65-69.

7. Cooper, C. L., \& Sutherland, V. J. (2000). Strategic Stress Management: An Organizational Approach. London: McMillan Press Limited.

8. Cooper, C. L., \& Williams, S. (1998). Measuring Occupational Stress: Development of the Pressure Management Indicator. Journal of Occupational Health Psychology, Vol. 3, No. 4, , pp. 306-321

9. Curran, C. (2001). The Phenomenon of On-Line Learning. European Journal of Education, Vol. 36, No. 2, retrieved from http://www.jstor.org/page/info/about/policies/terms.jsp, pp:113-132.

10. DeFrank, R. S., \& Ivancevich, J. M. (1998). Stress on the Job: An Executive Update. The Academy of Management Executive (1993-2005), Vol. 12, No. 3 (Aug., 1998), Retrieved from http://www.jstor.org/stable/4165477 on December 24, 2011, pp.55-66.

11. Edlington, B. (2007). Overcoming barriers to learning through e-learning. Adelaide, Australia: 30th HERDSA Annual Conference.

12. Galinsky, E., Kim, S., \& Bond, J. T. (2001). Feeling Over-worked: When Work becomes too Much. New York (NY): Families and Work Institute.

13. Garcia, B. C. (2012). New e-Learning Environments:e-Merging Networks in the Relational Society ELearning-Theories, Designs, Software and Applications (pp. pp. 1-21). Rijeka, Croatia: InTech.

14. Gibson, V. M. (1993). Stresss in Work Place: A Hidden Cost Factor. HR Focus, $70(1), 15$.

15. Ibrahim, A., Mohd Rozar, N. B., Razik, M. A. B., \& Kormin, K. B. (2011). Comparing Effectiveness E-learniing Training and Traditional Training in Industrial Health and Safety, UK.

16. Jamal, M., \& Baba, V. V. (2000). Job Stress and Burnout among Canadian Managers and Nurses: An Empirical Examination. Canadian Journal of Public Health, 91(6), pp. 454-460.

17. Judd, C. M., \& Kenny, D. A. (1981). Process analysis estimating mediation in treatment evaluations. Evaluation review, 5(5), 602-619.

18. Kazmi, R., Amjad, S., \& Khan, D. (2008). Occupational stress and its effect on Job performance: A case study of Medical House Officers of District Abbotabad. Journal of Ayub Medical College. 20, pp. 135-139. 
19. Lawless, N., \& Allan, J. (2004). Understanding and reducing stress in collaborative elearning. Electronic Journal of E-Learning, 2(1), pp. 121-127.

20. Lobel, S. A. (2003). It would even be good for business, In J. deGraaf(Ed.), Take Back your time day Handbook, pp.178-184. SanFrancisco:: Berrett-Koehler.

21. MacKinnon, D. P., Lockwood, C. M., Hoffman, J. M., West, S. G., \& Sheets, V. (2002). A comparison of methods to test mediation and other intervening variable effects. Psychological methods, 7(1), 83.

22. Masrom, M. (2007). Technology Acceptance Model and E-learning. Paper presented at the 12th International Conference on Education, Sultan Hassanal Bolkiah Institute of Education Universiti Brunei Darussalam, Brunei Darussalam.

23. NIOSH Working Group, P. N.-. (Producer). (1999). http://www.cdc.gov/. Stress.. At Work, NIOSH Publications and Products. Retrieved from http://www.cdc.gov/niosh/docs/99-101/

24. Nycz, M., \& Cohen, E. (2007). The basics for understanding e-learning effective online teaching (pp. pp:1-17). Santa Rosa: CA: Informing Science Press.

25. P, S. (Producer). (2007, October 09). Retrieved from http://aboutelearning.blogspot.com/

26. Rahman, M., \& Zanzi, A. (1995). A Comparison Of Organizational Structure, Job Stress, And Satisfaction In Audit And Management Advisory Services (MAS) In CPA Firms. Journal of Managerial Issues, Vol. 7, No. 3, Published by Pittsburg State University, Retrieved from http://www.jstor.org/stable/40604069, on |September 07, 2011, pp. 290-305.

27. Rajeshwari, T. R. (1992). Employee Stress: A Study with Reference to Bank Employees. Indian Journal of Industrial Relations, Vol. 27, No. 4, Published by Indian Journal of Industrial Relations, Vol. 27, No. 4, Published by Shri Ram Centre for Industrial Relations and Human Resources, Retrieved from http://www.jstor.org/stable/27767223, pp. 419-429.

28. Robins, S. P. (2001). Organizational Behavior. 9th. New Jersey: Prentice-Hall, Inc.

29. Scott, C. J. (2010). Optimal Stress: Living in Your Best Stress Zone. New Jersy: John Wiley \& Sons, Inc.

30. Sharma, G. K. (Producer). (2012, March 06). http://EzineArticles.com/7040184. Retrieved from http://ezinearticles.com/?Custom-e-Learning-Solutions-forCorporate-Firms\&id=7040184

31. Smith, M. (Producer). (2011, December 30). Retrieved from The Fiji Times Online,"Psychology of Suicide", http://www.fijitimes.com/story.aspx?id=183527

32. Stinchcomb, J. B. (2004). Searching for Stress in All the Wrong Places: Combating Chronic Organizational Stressors in Policing. Police Practice and Research, Vol. 5, No. 3,, pp. 259-277.

33. Strother, J. B. (2002). An Assessment of the DEffectiveness of E-Learning in Corporate Training Programs. The International Review of Research in Open and 
DIstance Learning, Vol. 3, No. 1; Retrieved from http://www.irrodl.org/index.php/irrodl/index on July 30, 2012.

34. Subha, I., \& Ahmad, S. (2009). Impact Of Stress On Employee Productivity, Performance and Turnover; An Important Managerial Issue International Review of Business Research Papers, Vol. 5 No. 4, pp. 468-477

35. Sutherland, V. J., \& Cooper, C. L. (1996). "Stress prevention in the Offshore Oil and Gas Exploration and Production Industry" Working Paper CONDI/T/WP.1/1996. Manchester, UK: Manchester School of Management, University of Manchester Institute of Science and Technology.

36. Tai, L. (2008). Corporate E-Learning: An Inside view of IBM's Solutions. New York: Oxford University Press.

37. Tennant, C. (2001). Work-related stress and depressive disorders. Journal of Psychosomatic Research 51 pp. 697-704.

38. Zhang, X., \& Yuhao, L. (2012). Knowledge Building in E-Learning eLEARNING - THEORIES,DESIGN, SOFTWARE AND APPLICATIONS (pp. pp. 23-36). Croatia: InTech.

39. Zornada, M. (2005). E-Learning and the Changing Face of Corporate Training and Development. pp: 59-75. 